\title{
Kekuatan Pembuktian Akta Notaris Terkait Ketidakcakapan Penghadap Setelah Penandatanganan Akta
}

\author{
Adella Tiara Maharani \\ Magister Kenotariatan Universitas Islam Indonesia Yogyakarta Indonesia \\ Jln. Cik Di Tiro No.1 Yogyakarta Indonesia \\ adellatiara01gmail.com
}

\begin{tabular}{ll}
\hline Key Word: & Abstract \\
Authentic deed; & A written agreement can be converted into a Notary deed which is an authentic deed \\
power of evidence & if it is made before a Notary as an official authorized to make an authentic deed in \\
accordance with Article 15 paragraph (1) of Law Number 2 of 2014 on Amendments \\
to Law Number 30 of 2004 on Public Notary. In accordance with Article 1320 of the \\
Civil Code, the conditions for an agreement to be deemed valid are mutual consent, \\
capacity of the parties, subject matter and lawful cause. This study aims to \\
determine and analyze the power of evidence of the Notary deed in relation to the \\
incompetence of the applicant after the signing of the deed and legal settlement of the \\
deed whose witnesses are later declared incompetent. This type of research is \\
juridical-empirical. This study uses primary legal materials and secondary legal \\
materials. The results of this study conclude that the Notary deed has the external \\
power formal and material evidence. The Notary Deed made by the applicant who \\
lost their capacity after signing the deed is still valid before the lawsuit and the \\
judge's decision
\end{tabular}

\section{Kata-kata Kunci: Abstrak}

Akta otentik; Perjanjian tertulis dapat diubah menjadi akta Notaris yang merupakan akta kekuatan otentik jika dibuat di depan Notaris sebagai pejabat yang berwenang pembuktian membuat akta otentik sesuai dengan Pasal 15 ayat (1) Undang-Undang Nomor 2 Tahun 2014 tentang Perubahan Atas Undang-Undang Nomor 30 Tahun 2004 tentang Jabatan Notaris. Sesuai dengan Pasal 1320 Kitab Undang-Undang Hukum Perdata syarat sah perjanjian yakni adanya kesepakatan, kecakapan para pihak, obyek tertentu dan adanya kausa yang halal. Penelitian ini bertujuan untuk mengetahui dan menganalisis kekuatan pembuktian akta Notaris terkait ketidakcakapan penghadap setelah penandatanganan akta dan penyelesaian hukum terhadap akta yang penghadapnya dikemudian hari dinyatakan tidak cakap. Jenis penelitian yang dibuat adalah yuridis-empiris. Penelitian ini menggunakan bahan hukum primer dan bahan hukum sekunder. Hasil penelitian ini menyimpulkan bahwa akta Notaris memiliki kekuatan pembuktian lahiriah, formal dan materil. Akta Notaris yang dibuat oleh penghadap yang kehilangan kecakapan setelah penandatanganan akta masih sah dan berlaku sebelum adanya gugatan dan putusan dari Hakim.

\section{Pendahuluan}

Manusia sebagai makhluk sosial tidak akan lepas dari suatu perjanjian. Adanya kecakapan untuk bertindak dalam hukum sesuai dengan Pasal 1320 Kitab UndangUndang Hukum Perdata (KUHPerdata) merupakan syarat subjektif kedua atas terbentuknya perjanjian yang sah diantara para pihak. Dalam KUHPerdata hal yang berhubungan dengan kecakapan dan kewenangan bertindak dalam rangka pembuatan untuk kepentingan pihak orang-perorangan diatur dalam Pasal 1329 sampai dengan 
Pasal 1331. Dalam Pasal 1329 KUHPerdata dinyatakan, bahwa setiap orang adalah cakap untuk melakukan perikatan-perikatan, kecuali oleh undang-undang dinyatakan tidak cakap. ${ }^{1}$ Sedangkan di dalam Pasal 1330 diberikan batasan orang-orang mana saja yang tidak cakap dan berwenang untuk bertindak dalam hukum, khususnya ketidakcakapan dalam membuat perjanjian yakni orang yang belum dewasa, orang yang dibawah pengampuan, seorang perempuan dalam hal yang ditetapkan oleh undang-undang dan pada umumnya semua orang kepada siapa undang-undang telah melarang membuat perjanjian-perjanjian tertentu. ${ }^{2}$ Tidak cakap menurut hukum adalah mereka yang oleh undang-undang dilarang melakukan tindakan hukum, terlepas dari apakah secara faktual ia mampu memahami konsekuensi tindakannya.

Perjanjian yang dikenal dalam masyarakat dari cara pembuatannya ialah perjanjian lisan dan perjanjian tertulis. Perjanjian tertulis dapat diubah menjadi akta Notaris yang merupakan akta otentik jika dibuat di depan Notaris sebagai pejabat yang berwenang membuat akta otentik sesuai dengan Pasal 15 ayat (1) Undang-Undang Nomor 2 Tahun 2014 tentang Perubahan Atas Undang-Undang Nomor 30 Tahun 2004 tentang Jabatan Notaris. Akta otentik menurut Pasal 1868 KUHPerdata adalah suatu akta yang dibuat dalam bentuk yang ditentukan undang-undang oleh atau di hadapan pejabat umum yang berwenang untuk itu di tempat akta itu dibuat. ${ }^{3}$ Akta otentik harus memenuhi syarat materil dan syarat formil. Syarat materil akta otentik diatur dalam ketentuan Pasal 1320 KUHPerdata, sedangkan syarat formil diatur dalam ketentuan Pasal 38 UndangUndang Nomor 2 Tahun 2014 tentang Perubahan Atas Undang-Undang Nomor 30 Tahun 2004 tentang Jabatan Notaris (UUJN). Apabila perjanjian yang dituangkan dalam akta otentik tidak memenuhi syarat dalam Pasal 1320 KUHPerdata, maka akta tersebut batal demi hukum. Apabila akta Notaris tidak memenuhi syarat formil dalam Pasal 38 UUJN maka akta tersebut menjadi akta di bawah tangan.

Tulisan-tulisan otentik berupa akta otentik yang dibuat dalam bentuk yang sudah ditentukan oleh undang-undang, dibuat dihadapan pejabat-pejabat (pegawai umum) yang diberi wewenang dan di tempat dimana akta tersebut dibuat. ${ }^{4}$ Akta Notaris tidak memenuhi syarat sebagai keputusan tata usaha negara yang bersifat konkrit, individual dan final. Akta merupakan formulasi keinginan atau kehendak para pihak yang dituangkan dalam akta Notaris yang dibuat dihadapan atau oleh Notaris dan bukan kehendak Notaris. ${ }^{5}$ Tulisan-tulisan di bawah tangan atau disebut juga akta di bawah tangan dibuat dalam bentuk yang tidak ditentukan oleh undang-undang, tanpa perantara atau tidak dihadapan Pejabat Umum yang berwenang. Akta otentik maupun akta di bawah tangan dibuat dengan tujuan untuk dipergunakan sebagai alat bukti.

Notaris adalah pejabat umum yang diangkat oleh Pemerintah untuk membantu masyarakat umum dalam hal membuat perjanjian-perjanjian yang ada atau timbul dalam

\footnotetext{
${ }^{1}$ Pasal 1329 Kitab Undang-Undang Hukum Perdata.

${ }^{2}$ Sjairurrachman \& Habib Adjie, Aspek Pertanggungjawaban Notaris dalam Pembuatan Akta, Mandar Maju, Bandung, 2011, hlm. 139.

3 Pasal 1868 Kitab Undang-Undang Hukum Perdata.

${ }^{4}$ Habib Adjie, Hukum Notaris Indonesia; Tafsir Tematik Terbadap UU No. 30 Tabun 2004 Tentang Jabatan Notaris, Refika Aditama, Bandung, 2009, hlm. 120.

${ }^{5}$ Habib Adjie, Sanksi Perdata dan Administratif Terbadap Notaris Sebagai Pejabat Publike, Refika Aditama, Bandung, 2008, hlm. 15.
} 
masyarakat. Perlunya perjanjian-perjanjian tertulis ini dibuat dihadapan seorang Notaris adalah untuk menjamin kepastian hukum bagi para pihak yang melakukan perjanjian. Perjanjian digunakan dalam berbagai hubungan bisnis, kegiatan di bidang perbankan, pertanahan, kegiatan sosial, dan lain-lain, kebutuhan akan pembuktian tertulis berupa akta otentik makin meningkat sejalan dengan berkembangnya tuntutan akan kepastian hukum dalam berbagai hubungan ekonomi dan sosial, baik pada tingkat nasional, regional, maupun global.

Notaris berperan melaksanakan sebagian tugas negara dalam bidang hukum keperdataan, dan kepada Notaris dikualifikasikan sebagai Pejabat Umum yang berwenang untuk membuat akta otentik, dan akta merupakan formulasi keinginan atau kehendak (wilsvorming) para pihak yang dituangkan dalam akta Notaris yang dibuat di hadapan atau oleh Notaris, dan kewenangan lainnya sebagaimana dimaksud dalam UUJN. ${ }^{6}$

Dalam menjalankan kewenangannya Notaris dalam membuat suatu akta Notaris harus sesuai dengan ketentuan yang diatur dalam UUJN. apabila tidak memenuhi salah satu atau beberapa unsur tersebut maka suatu akta Notaris tersebut mengakibatkan kebatalan maupun pembatalan akta Notaris. Hal ini menunjukkan bagaimana pertanggungjawaban Notaris dalam melaksanakan kewenangan maupun kewajibannya.

Suatu akta/perjanjian yang dibuat dihadapan Notaris memiliki tingkat pembuktian yang sempurna sebagaimana diatur dalam Pasal 1870 KUHPerdata. Pembuktian yang sempurna disini bermakna bahwa tidak dapat disangkal keberadaannya karena akta/perjanjian tersebut dibuat oleh Notaris dan juga tidak dapat disangkal isinya, hal ini dikarenakan Notaris telah memastikan bahwa para pihak dalam perjanjian memahami isi dari perjanjian dengan cara membacakannya dihadapan para pihak dan memastikan bahwa tanda tangan tersebut sesuai dengan aslinya. Tetapi apabila seseorang yang telah menandatangani akta tersebut kehilangan kecakapan, maka bagaimanakah kekuatan pembuktian akta tersebut.

\section{Rumusan Masalah}

Rumusan masalah yang menjadi fokus pengkajian dalam penelitian ini, pertama, bagaimana kekuatan pembuktian akta Notaris terkait ketidakcakapan penghadap setelah penandatanganan akta? Kedua, bagaimana penyelesaian hukum terhadap akta Notaris dimana penghadap dikemudian hari dinyatakan tidak cakap?

\section{Tujuan Penelitian}

Penelitian ini bertujuan untuk pertama, menganalisis akibat hukum dari kekuatan pembuktian akta Notaris terkait ketidakcakapan penghadap setelah penandatanganan akta. Kedua, menganalisis penyelesaian hukum terhadap akta dimana penghadap dikemudian hari dinyatakan tidak cakap.

${ }^{6}$ Pasal 1 angka 1 dan Pasal 15 ayat (1) Undang-Undang Nomor 2 Tahun 2014 tentang Perubahan Atas Undang-Undang Nomor 30 Tahun 2004 tentang Jabatan Notaris. 


\section{Metode Penelitian}

Metode analisis dalam penelitian hukum ini bersifat yuridis-empiris. Penelitian ini berdasarkan apa yang dilakukan secara langsung di lapangan, kemudian dikaitkan dengan analisa-analisa terhadap perundang-undangan yang mengatur setiap permasalahan yang diteliti serta mengarah pada studi kepustakaan untuk memperoleh data sekunder yang ada sehingga dapat diperoleh hubungan antara peraturan perundang-undangan dengan peraturan lainnya dan penerapannya di dalam kasus ini, khususnya pada kekuatan pembuktian akta Notaris terkait ketidakcakapan penghadap setelah penandatanganan akta.

\section{Hasil Penelitian dan Pembahasan}

\section{Kekuatan Pembuktian Akta Notaris Terkait Ketidakcakapan Penghadap Setelah Penandatanganan Akta}

Sesuai dengan Pasal 15 ayat (1) UUJN diatur mengenai kewenangan Notaris yakni Notaris berwenang membuat akta otentik mengenai semua perbuatan, perjanjian, dan penetapan yang diharuskan oleh peraturan perundang-undangan dan atau yang dikehendaki oleh yang berkepentingan untuk dinyatakan dalam akta otentik, menjamin kepastian tanggal pembuatan akta, menyimpan akta, memberikan grosse, salinan dan kutipan akta, semuanya itu sepanjang pembuatan akta tidak ditugaskan atau dikecualikan kepada pejabat lain atau orang lain yang ditetapkan oleh undang-undang.

Alat bukti yang sah atau diakui oleh hukum diatur dalam Pasal KUHPerdata yang terdiri dari bukti tulisan, bukti dengan saksi-saksi, persangkaan-persangkaan, pengakuan dan sumpah. ${ }^{7}$ Pembuktian dengan tulisan dapat dilakukan dengan tulisan-tulisan otentik maupun tulisan-tulisan di bawah tangan. Akta otentik dan juga akta di bawah tangan dibuat dengan tujuan untuk digunakan sebagai alat bukti.

Perbedaan antara akta otentik dan akta di bawah tangan yaitu dalam nilai pembuktiannya. Akta otentik mempunyai kekuatan pembuktian yang sempurna, sedangkan akta di bawah tangan mempunyai kekuatan pembuktian sepanjang para pihak yang membuat akta mengakuinya atau dengan kata lain tidak ada penyangkalan dari salah satu pihak. Berdasarkan pada pengertian akta sebagaimana disebutkan di atas, maka selanjutnya fungsi akta bagi pihak-pihak yang berkepentingan adalah sebagai syarat untuk menyatakan adanya suatu perbuatan hukum, sebagai alat pembuktian, dan sebagai alat pembuktian satu-satunya. ${ }^{8}$

Dasar untuk pembuatan suatu akta Notaris berasal dari keterangan dan juga penjelasan yang diberikan oleh para penghadap atau melalui hasil wawancara maupun bukti-bukti yang diberikan kepada Notaris yang selanjutnya dapat dituangkan ke dalam akta Notaris. Kekuatan pembuktian pada setiap akta otentik menurut pendapat umum yakni, kekuatan pembuktian lahiriah (uitwendige bewijskracht), kekuatan pembuktian formal (formele bewijskracht), dan kekuatan pembuktian materil (materiele bewijskracht). Ketiga aspek tersebut merupakan kesempurnaan dari akta Notaris sebagai akta otentik.

\footnotetext{
7 Pasal 1866 Kitab Undang-Undang Hukum Perdata

8 A. Pitlo, Pembuktiandan Daluwarsa, Alih Bahasa M. Isa Arief, Intermasa, Jakarta, 1986, hlm. 54.
} 
Apabila dapat dibuktikan dalam suatu persidangan di pengadilan bahwa terdapat salah satu aspek yang tidak terpenuhi atau tidak benar maka akta itu mempunyai kekuatan pembuktian sebagai akta di bawah tangan. Dalam hukum perjanjian terdapat akibat hukum tertentu apabila syarat subjektif maupun syarat objektif tidak terpenuhi. Jika syarat subjektif tidak terpenuhi maka perjanjian dapat dibatalkan (vernietigbaar) sepanjang terdapat permintaan dari para pihak yang berkepentingan. Jika syarat objektif tidak terpenuhi maka perjanjian batal demi hukum (nietig) tanpa perlu permintaan dari para pihak yang berkepentingan. Dengan demikian perjanjian dianggap tidak pernah ada dan tidak mengikat siapapun.

Notaris wajib menjamin kepastian hari, tanggal, bulan, tahun dan pukul menghadap yang tercantum atau disebutkan pada awal akta otentik sebagai bukti bahwa pihak menghadap dan menandatangani akta pada saat itu dan semua prosedur pembuatan akta sudah dilakukan sesuai dengan peraturan perundang-undangan yang berlaku. Notaris harus memastikan bahwa semua kelengkapan dan keabsahan alat bukti atau dokumen yang diperlihatkan kepada Notaris adalah benar.

Berdasarkan wawancara dengan Rio Kustianto Wironegoro Notaris di Kota Yogyakarta pada Kamis 26 November 2020, penghadap harus dipastikan memiliki kecakapan pada waktu pembuatan akta otentik sesuai dengan Pasal 39 UUJN. Sebagai Notaris juga harus bisa memastikan bahwa semua yang diberikan atau disampaikan oleh penghadap adalah benar. Apabila terdapat penghadap yang kehilangan kecakapannya setelah akta ditandatangani maka akta tersebut masih sah berlaku karena pada saat pembuatan akta penghadap masih memiliki kecakapan dan nomor akta sudah terdaftar. ${ }^{9}$

Berdasarkan wawancara dengan Hendrik Budi Untung Notaris di Kota Yogyakarta pada Jumat 27 November 2020, akta yang sudah dibuat dan ditandatangani oleh penghadap apabila dikemudian hari penghadap kehilangan kecakapannya, maka akta yang sudah dibuat dan ditandatangani tersebut masih sah dan berlaku. Penghadap yang datang untuk membuat suatu akta perlu membawa surat keterangan kesehatan dari dokter, sehingga dapat melakukan perjanjian dan pembuatan akta secara sah dan sesuai dengan ketentuan peraturan perundang-undangan yang berlaku. Selama Notaris menjalankan tugas dan jabatannya, belum pernah ada pihak keluarga dari penghadap yang apabila dikemudian hari kehilangan kecakapannya menuntut akan akta yang sudah dibuat oleh penghadap sebelumnya. ${ }^{10}$

Otentik atau tidaknya suatu akta Notaris tidak cukup hanya apabila akta dibuat oleh dan atau dihadapan Notaris saja, selain itu tata cara pembuatan akta otentik harus sesuai dengan ketentuan peraturan perundang-undangan yang berlaku. Apabila suatu akta dibuat oleh seorang pejabat yang tidak memiliki wewenang dan tidak sesuai dengan syarat dari peraturan perundang-undangan yang berlaku, maka akta itu tidak dapat dikatakan sebagai akta otentik dan juga kekuatan pembuktian akta itu sangatlah lemah.

\footnotetext{
9 Wawancara dengan Rio Kustianto Wironegoro, Notaris, di Kota Yogyakarta, 26 November 2020.

10 Wawancara dengan Hendrik Budi Untung Notaris di Kota Yogyakarta, 27 November 2020.
} 


\section{Penyelesaian Hukum terhadap Akta di Mana Penghadap Dikemudian Hari Dinyatakan Tidak Cakap}

Dalam hukum kenotariatan jika terdapat pihak yang mempermasalahkan akta Notaris maka hal yang harus dilaksanakan yakni:

1. Para pihak dapat datang kembali ke Notaris untuk membuat akta pembatalan atas akta tersebut dan dengan demikian akta yang dibatalkan sudah tidak mengikat lagi bagi para pihak dan para pihak yang menanggung segala akibat dari pembatalan akta tersebut.

2. Jika para pihak tidak sepakat akta yang bersangkutan untuk dibatalkan, maka salah satu pihak dapat menggugat pihak lainnya dengan gugatan untuk mendegradasikan akta Notaris menjadi akta di bawah tangan. Setelah didegradasikan, maka Hakim yang memeriksa gugatan dapat memberikan penafsiran tersendiri atas akta Notaris yang sudah didegradasikan, apakah tetap mengikat para pihak atau dibatalkan. Hal ini tergantung pada pembuktian dan penilaian hukum. ${ }^{11}$

Jika salah satu pihak ada yang merasa dirugikan oleh akta yang dibuat Notaris, maka pihak yang merasa dirugikan tersebut dapat mengajukan guguatan berupa tuntutan ganti rugi kepada Notaris yang bersangkutan, dengan kewajiban penggugat, yaitu dalam gugatan harus dapat dibuktikan bahwa kerugian tersebut merupakan akibat langsung dari akta Notaris. Apabila terdapat pihak yang mengajukan gugatan untuk menyatakan bawa akta Notaris tersebut tidak sah, maka harus dapat dibuktikan ketidakabsahan dari aspek lahiriah, formal dan materil dari akta Notaris tersebut. Penyangkalan dapat berupa:

a. Lahiriah (Uitwendige Bewijskracht)

Penyangkalan atau pengingkaran bahwa secara lahiriah akta Notaris sebagai akta otentik, maka penilaian pembuktiannya harus didasarkan kepada syarat-syarat akta Notaris sebagai akta otentik. Pembuktian semacam ini harus dilakukan melalui upaya gugatan ke pengadilan. Penggugat harus dapat membuktikan bahwa secara lahiriah akta yang menjadi objek gugatan bukan akta Notaris. ${ }^{12}$

b. Formal (Formele Bewijskracht)

Apabila aspek ini dipermasalahkan oleh para pihak, maka harus dapat dibuktikan formalitas dari akta, yaitu harus dapat membuktikan ketidakbenaran hari, tanggal, bulan, tahun dan pukul menghadap, membuktikan ketidakbenaran mereka yang menghadap, membuktikan ketidakbenaran apa yang dilihat, disaksikan dan didengar oleh Notaris. Selain itu juga harus dapat membuktikan ketidakbenaran pernyataan atau keterangan para pihak yang diberikan/disampaikan dihadapan Notaris, dan ketidakbenaran tandatangan para pihak, saksi dan Notaris ataupun terdapat prosedur pembuatan akta yang tidak dilakukan. Dengan kata lain, pihak yang mempermasalahkan akta tersebut harus melakukan pembuktian terbalik untuk menyangkal aspek formal dari akta Notaris. ${ }^{13}$

c. Materil (Materiele Bewijskracht)

Keterangan atau pernyataan dari para pihak yang dituangkan dalam akta pejabat (berita acara), atau keterangan para pihak yang diberikan/disampaikan di

11 Habib Adjie, Sanksi Perdata dan Administratif Terhadap Notaris Sebagai Pejabat Publik, Refika Aditama, Bandung, 2008, hlm. 58.

12 Ibid., hlm. 72.

${ }^{13}$ Ibid., hlm. 73. 
hadapan Notaris dan para pihak harus dinilai benar. Apabila ternyata pernyataan para penghadap menjadi tidak benar, maka hal tersebut menjadi tanggungjawab para pihak itu sendiri. Jika akan membuktikan aspek materil dari akta, maka yang bersangkutan harus dapat membuktikan bahwa Notaris tidak menerangkan atau menyatakan yang sebenarnya dalam akta atau para pihak yang telah berkata benar dihadapan Notaris menjadi tidak benar. ${ }^{14}$

Ketiga aspek di atas merupakan kesempurnaan akta Notaris sebagai akta otentik dan siapapun terikat oleh akta tersebut. Jika dapat dibuktikan dalam suatu persidangan pengadilan, bahwa ada salah satu aspek yang tidak benar, maka akta itu hanya mempunyai kekuatan pembuktian sebagai akta dibawah tangan atau akta tersebut didegradasikan kekuatan pembuktiannya sebagai akta yang mempunyai kekuatan pembuktian sebagai akta dibawah tangan.

Pembuatan akta Notaris harus memenuhi syarat materil dan syarat formil sesuai dengan Pasal 1320 KUHPerdata. Syarat sah perjanjian yang diatur di dalam pasal tersebut yakni adanya kata sepakat bagi mereka yang mengikatkan dirinya, kecakapan para pihak untuk membuat suatu perikatan, suatu hal tertentu, dan suatu sebab (causa) yang halal. Apabila terdapat salah satu syarat dalam ketentuan Pasal 1320 tidak terpenuhi, dapat mengakibatkan perjanjian cacat hukum, yang keabsahannya dapat dipertanyakan dan perjanjian dapat batal atau dapat dibatalkan oleh pihak ketiga yang berkepentingan. Syarat pertama dan kedua merupakan syarat subjektif yang mengatur mengenai orang atau subjek hukum yang mengadakan suatu perjanjian dan apabila syarat subjektif tidak terpenuhi, maka akta dapat dibatalkan. Syarat ketiga dan keempat merupakan syarat objektif yang mengenai isi perjanjian dan apabila syarat objektif ini tidak terpenuhi atau dilanggar maka perjanjian atau akta yang telah dibuat batal demi hukum.

Berdasarkan Pasal 1320 KUHPerdata, cacat dalam perjanjian diancam kebatalan baik dalam bantuk yang dibatalkan maupun batal demi hukum, sebagaimana terurai sebagai berikut: 15

1. Perjanjian yang dapat dibatalkan

Pihak dalam perjanjian maupun pihak ketiga dapat mengajukan pembatalan atas perjanjian baik sebelum perikatan yang lahir dari perjanjian itu dilaksanakan maupun setelahnya.

2. Perjanjian yang batal demi hukum

Perjanjian yang batal demi hukum terjadi apabila terdapat pelanggaran terhadap syarat objektif dari sahnya suatu perjanjian.

Menurut JH. Niewenhuis yang menyatakan bahwa, suatu perjanjian yang tidak memenuhi syarat sah sebagaimana diatur dalam Pasal 1320 KUHPerdata, baik syarat subjektif maupun syarat objektif akan mempunyai akibat-akibat sebagai berikut: ${ }^{16}$

a. Non eksistensi, apabila tidak ada kesepakatan maka tidak timbul perjanjian;

${ }^{14}$ Ibid., hlm. 74.

15 Sjaifurrachman dan Habib Adjie, Op. Cit., hlm. 131.

16 Agus Yudha Hernoko, Hukum Perjanjian Asas Proporsionalitas Dalam Kontrak. Komersial, LaksBang Mediatama, Surabaya, 2008, hlm. 139. 
b. Vernietegbaar atau dapat dibatalkan, apabila kontrak tersebut lahir karena adanya cacat kehendak wilsgebreke atau karena ketidakcakapan onbekwaamheid berarti hal ini terkait dengan unsur subjektif, sehingga berakibat kontrak tersebut dapat dibatalkan;

c. Nietig atau batal demi hukum, apabila terdapat kontrak yang tidak memenuhi syarat objek tertentu atau tidak mempunyai causa atau causanya tidak diperbolehkan berarti hal ini terkait dengan unsur subjektif, sehingga berakibat kontrak tersebut batal demi hukum.

Kesalahan materil dalam suatu akta yang dibuat oleh Notaris dapat terjadi karena adanya pihak yang menyelundupkan suatu perbuatan melawan hukum yang mengakibatkan akta yang dibuatnya tidak mempunyai kekuatan pembuktian secara materil walaupun secara lahiriah dan formil sudah sesuai dengan ketentuan yang sudah ditentukan oleh peraturan perundang-undangan, maka akta yang mempunyai salah satu unsur kesalahan tersebut dapat langsung batal secara hukum. ${ }^{17}$

Membatalkan akta Notaris berarti secara lahiriah tidak mengakui akta tersebut, dengan demikian akta tersebut bukanlah akta Notaris. Penilaian akta Notaris secara lahiriah harus dibuktikan dari awal sampai akhir akta. Apabila dapat dibuktikan bahwa akta Notaris tersebut tidak memenuhi syarat sebagai sebuah akta Notaris maka akta tersebut akan mempunyai nilai pembuktian sebagaimana akta dibawah tangan yang mana penilaian pembuktiannya tergantung kepada pengakuan para pihak dan hakim.

Perkara pidana dan perdata akta Notarsi senantiasa dipermasalahkan dari aspek formal, terutama mengenai kepastian hari, tanggal, bulan, tahun dan pukul menghadap, pihak (siapa) yang menghadap Notaris, tanda tangan yang menghadap, salinan akta tidak sesuai dengan minuta akta, salinan akta ada namun tanpa dibuat minuta akta, dan Minuta akta tidak ditandatangani secara lengkap, tapi minuta akta dikeluarkan. ${ }^{18}$

Pemeriksaan terhadap Notaris selaku tersangka atau terdakwa harus didasarkan kepada tata cara pembuatan akta Notaris, yaitu dengan melakukan pengenalan terhadap penghadap berdasarkan identitasnya yang diperlihatkan kepada Notaris; Menanyakan, kemudian mendengarkan dan mencermati keinginan atau kehendak para pihak tersebut; Memeriksa bukti surat yang berkaitan dengan keinginan atau kehendak para pihak; Memberikan saran dan membuat kerangka akta untuk memenuhi keinginan atau kehendak para pihak; Memenuhi segala teknik administrasi pembuatan akta Notaris, seperti pembacaan, penandatanganan, memberikan salinan, dan pemberkasan untuk minuta; dan Melakukan kewajiban lain yang berkaitan dengan pelaksanaan tugas jabatan Notaris.

Dalam memeriksa Notaris yang berkaitan dengan akta yang telah dibuatnya, parameternya harus kepada prosedur pembuatan akta Notaris, dalam hal ini mengacu kepada UUJN. Apabila semua prosedur sudah dilakukan, maka akta yang telah dibuat oleh Notaris tetap mengikat bagi yang bersangkutan dan bagi mereka yang membuatnya dihadapan Notaris.

17 An Lisa Lubis, Analisis Yuridis Kesalahan Materil Akta Notaris Dan Akibat Hukumnya, USU, Medan, 2016, hlm. 19.

${ }^{18}$ Habib Adjie, Sanksi Perdata ..., Op. Cit., hlm. 75. 
Penelitian ini lebih menitikberatkan kepada bagaimana kekuatan pembuktian akta terkait ketidakcakapan penghadap setelah penandatanganan akta dan bagaimana penyelesaian hukum apabila terdapat pihak ketiga yang menggugat akta tersebut. Penulis telah melakukan wawancara kepada beberapa Notaris di Kota Yogyakarta dan selama Notaris tersebut melaksanakan tugas dan jabatannya belum pernah ada kejadian dimana pihak ketiga menggugat akta yang telah dibuat oleh seseorang yang dikemudian hari kehilangan kecakapannya, karena akta yang telah dibuat oleh Notaris pada saat itu tidak bertentangan dengan peraturan perundang-undangan yang berlaku dan sesuai dengan syarat sah perjanjian yang diatur dalam Pasal 1320 KUHPerdata. Sehingga akta yang telah dibuat masih tetap sah dan berlaku sebelum adanya gugatan dan putusan dari Hakim.

\section{Penutup}

Kekuatan pembuktian akta Notaris terkait ketidakcakapan penghadap setelah penandatanganan akta masih sah dan tetap berlaku karena pada saat pembuatan dan penandatanganan akta tersebut, penghadap masih memiliki kecakapan. Akta Notaris dianggap sah sampai ada pihak yang menyatakan akta tersebut tidak sah. Untuk menyatakan atau menilai akta tersebut tidak sah harus dengan gugatan ke pengadilan umum. Selama dan sepanjang gugatan berjalan sampai dengan adanya keputusan pengadilan yang mempunyai hukum tetap, maka akta Notaris tetap sah dan mengikat para pihak yang berkepentingan dengan akta tersebut. Apabila terdapat salah satu syarat dalam ketentuan Pasal 1320 yang tidak terpenuhi, dapat mengakibatkan perjanjian cacat hukum, yang keabsahannya dapat dipertanyakan dan perjanjian dapat batal atau dapat dibatalkan oleh pihak ketiga yang berkepentingan. Apabila syarat subjektif tidak terpenuhi maka, akta batal demi hukum dan apabila syarat objektif tidak terpenuhi, maka akta batal demi hukum. Membatalkan akta Notaris berarti secara lahiriah tidak mengakui akta tersebut, dengan demikian akta tersebut bukanlah akta Notaris. Penilaian akta Notaris secara lahiriah harus dibuktikan dari awal sampai akhir akta. Apabila dapat dibuktikan bahwa akta Notaris tersebut tidak memenuhi syarat sebagai sebuah akta Notaris maka akta tersebut akan mempunyai nilai pembuktian sebagaimana akta dibawah tangan yang mana nilai pembuktiannya tergantung kepada pengakuan para pihak dan hakim.

\section{Daftar Pustaka}

\section{Buku}

Adjie, Habib, Sanksi Perdata dan Administratif Terhadap Notaris Sebagai Pejabat Publik, Refika Aditama, Bandung, 2008.

Hukum Notaris Indonesia; Tafsir Tematik Terhadap UU No. 30 Tahun 2004 Tentang Jabatan Notaris, Refika Aditama, Bandung, 2009.

Lisa Lubis, An, Analisis Yuridis Kesalahan Materil Akta Notaris Dan Akibat Hukumnya, USU, Medan, 2016.

Pitlo, A., Pembuktiandan Daluwarsa, Alih Bahasa M. Isa Arief, Intermasa, Jakarta, 1986. 
Sjairurrachman \& Habib Adjie, Aspek Pertanggungjawaban Notaris dalam Pembuatan Akta, Mandar Maju, Bandung, 2011.

Yudha Hernoko, Agus, Hukum Perjanjian Asas Proporsionalitas Dalam Kontrak Komersial, LaksBang Mediatama, Surabaya, 2008.

\section{Peraturan Perundang-undangan}

Kitab Undang-Undang Hukum Perdata.

Undang-Undang Nomor 2 Tahun 2014 tentang Perubahan Atas Undang-Undang Nomor 30 Tahun 2004 tentang Jabatan Notaris. 